\title{
PENGARUH STRUKTUR KEPEMILIKAN INSTITUSIONAL, DEBT COVENANT DAN GROWTH OPPORTUNITIES TERHADAP KONSERVATISME AKUNTANSI
}

\author{
Enni Savitri \\ Fakultas Ekonomi, Universitas Riau \\ E-mail: enisavitri@gmail.com
}

\begin{abstract}
Abstrak
Penelitian ini bertujuan untuk menguji dan menganalisis pengaruh struktur kepemilikan institusional, debt covenant dan growth opportunities terhadap konservatisme akuntansi pada perusahaan real estate dan property yang terdaftar di bursa efek Indonesia. Populasi penelitian ini adalah perusahaan real estate dan property yang terdaftar di Bursa Efek Indonesia (BEI). Pemilihan sampel penelitian berdasarkan pada purposive sampling. Data yang digunakan dalam penelitian ini adalah data sekunder. Metode pengumpulan data yang digunakan dalam penelitian ini adalah metode dokumentasi. Pengujian hipotesis menggunakan alat analisis regresi berganda. Berdasarkan hasil analisis data dan pembahasan yang telah dikemukakan, dapat diambil kesimpulan sebagai berikut : 1) Secara parsial Kepemilikan Institusional tidak berpengaruh signifikan terhadap Konservatisme Akuntansi. 2) Secara parsial Debt Covenant tidak berpengaruh signifikan terhadap Konservatisme Akuntansi. 3) Secara parsial Growth Opportunities tidak berpengaruh signifikan terhadap Konservatisme Akuntansi.
\end{abstract}

Kata Kunci: Konservatisme Akuntansi, Kepemilikan Institusional, Debt Covenant dan Growth Opportunities

\section{PENDAHULUAN}

Laporan keuangan yang di hasilkan perusahaan juga memiliki keterbatasan dalam penyajian nya, beberapa bentuk keterbatasan itu adalah materiality, cost benefit relationship, sifat khusus suatu industri, dan konservatisme. Konservatisme adalah sikap hati-hati dalam menghadapi ketidakpastian suatu bisnis tertentu dengan mencoba mengurangi resikonya (Yadiati, 2007:60). Konsep ini mengakui beban dan kewajiban sesegera mungkin meskipun ada ketidakpastian tentang hasilnya, namun hanya mengakui pendapatan dan aset ketika sudah yakin akan diterima. Berdasarkan prinsip konservatisme, jika ada ketidakpastian tentang kerugian, maka akan mencatat kerugian. Sebaliknya, jika ada ketidakpastian tentang keuntungan, maka tidak harus mencatat keuntungan. Dengan demikian, laporan keuangan cenderung menghasilkan jumlah keuntungan dan nilai aset yang lebih rendah demi untuk berjaga-jaga.

Konservatisme merupakan prinsip yang dapat digunakan sebagai prosedur dalam menyusun 
laporan keuangan. Menurut Belkaoui, Wibiwo dan Sinaga (1997:198) prinsip konservatisme adalah suatu prinsip pengecualian atau modifikasi dalam pengertian bahwa prinsip itu berlaku sebagai suatu kendala bagi penyajian data akuntansi yang relevan dan dapat diandalkan. Prinsip konservatisme menyatakan bahwa pada waktu memilih antara 2 atau lebih teknik akuntansi yang dapat diterima, maka lebih diutamakan pilihan yang mempunyai dampak keuntungan lebih kecil terhadap modal pemegang saham.

Beberapa hal yang mempengaruhi konservatisme salah satunya yaitu struktur kepemilikan. Struktur kepemilikan memberi pengertian yang berbeda dalam hal mengawasi jalannya perusahaan. Struktur kepemilikan merupakan jenis institusi atau perusahaan yang memegang saham terbesar dalam suatu perusahaan (Wahyudi dan Pawestri, 2006) dalam (Sabrinna, 2010:15). Struktur kepemilikan institutional merupakan persentase jumlah saham yang dimiliki oleh perusahaan dibandingkan dengan jumlah saham yang dimiliki oleh pihak eksternal. Besar kecilnya struktur kepemilikan saham dapat mempengaruhi kebijakan dan pengambilan keputusan perusahaan (Deviyanti, 2012:28). Kepemilikan institutional akan mendorong peningkatan pengawasan kepada manajer agar mendapatkan kinerja yang optimal. Dengan adanya pengawasan yang optimal oleh institutional maka akan menghindari tindakan manajemen dalam membesar-besarkan laba yang tidak semestinya. Dengan menerapkan akuntansi yang konservatif maka tindakan membesar-besarkan laba dapat terhindari karena laba yang dihasilkan akan menjadi rendah jika dibandingkan dengan biaya-biaya.

Berbagai penelitian mengenai struktur kepemilikan institutional telah banyak dilakukan oleh peneliti sebelumnya, antara lain penelitian Widayati (2011) yang meneliti tentang pengaruh pajak, politik, struktur kepemilikan institutional, struktur kepemilikan manajerial, struktur kepemilikan publik, litigasi, Growth, dan debt covenant menunjukkan hasil bahwa pajak dan politik memiliki pengaruh terhadap konservatisme akuntansi sedangkan struktur kepemilikan institutional, struktur kepemilikan manajerial, struktur kepemilikan publik, litigasi, Growth dan debt covenant tidak memiliki pengaruh yang signifikan terhadap konservatisme.

Penelitian yang dilakukan oleh Deviyanti (2012) yang meneliti tentang faktor-faktor yang mempengaruhi penerapan konservatisme dalam akuntansi dengan menggunakan variabel dependen konservatisme dan variabel independen yaitu struktur kepemilikan manajerial, struktur kepemilikan institutional, struktur kepemilikan publik, ukuran perusahaan, dan leverage. Menunjukkan hasil bahwa struktur kepemilikan manajerial, struktur kepemilikan institutional dan struktur kepemilikan publik memiliki pengaruh yang signifikan dan negatif terhadap konservatisme. Sedangkan ukuran perusahaan dan leverage tidak memiliki pengaruh dan positif.

$$
\text { Watts dan Zimmerman }
$$
(1986) menyatakan bahwa motif 
pemilihan suatu metode akuntansi tidak terlepas dari teori akuntansi positif, salah satunya debt covenant hypothesis. Debt covenant hypothesis memprediksi bahwa manajer ingin meningkatkan laba dan aktiva untuk mengurangi biaya renegoisasi kontrak hutang ketika perusahaan memutuskan perjanjian hutangnya. Oleh karenanya, manajer akan berusaha memilih suatu metode yang cenderung tidak konservatif untuk merendahkan batasan kredit dan mengurangi biaya kesalahan teknis.

Evana (2010) yang meneliti tentang pengaruh kontrak hutang (debt covenant), good corporate governance, dan pertumbuhan perusahaan menunjukan hasil bahwa good corporate governance yang diproksikan melalui jumlah dewan komisaris dan debt covenant yang di proksikan melalui debt to equity ratio memiliki pengaruh terhadap konservatisme sedangkan pertumbuhan perusahaan dengan proksi perubahan earning per share tidak memiliki pengaruh terhadap penggunaan akuntansi konservatif. Selain itu penelitian lainnya dilakukan oleh Astarini (2011) meneliti tentang faktor-faktor yang mempengaruhi pilihan perusahaan terhadap konservatisme akuntansi, struktur kepemilikan memiliki pengaruh yang signifikan terhadap konservatisme sedangkan debt covenant dan Growth opportunities tidak memiliki pengaruh yang signifikan terhadap konservatisme.

Faktor lain yang mempengaruhi konservatisme yaitu Growth opportunities, Growth atau pertumbuhan perusahaan merupakan cerminan dari nilai suatu perusahaan, dimana berhubungan dengan kelangsungan hidup perusahaan (Evana, 2011:4). Sedangkan Growth opportunities adalah kesempatan untuk tumbuh perusahaan. Perusahaan yang menggunakan akuntansi yang konservatif akan memiliki tingkat pertumbuhan perusahaan yang tinggi hal ini disebabkan karena terdapat cadangan tersembunyi yang dapat digunakan untuk investasi. Dengan semakin tinggi tingkat pertumbuhan perusahaan maka semakin tinggi perusahaan untuk memilih akuntansi yang konservatif.

Menurut penelitian Resti (2012) yang membahas tentang faktor- faktor yang mempengaruhi konservatisme akuntansi menyatakan bahwa Growth opportunities, litigasi, pajak, kontrak hutang, struktur kepemilikan memiliki pengaruh yang signifikan terhadap konservatisme. Sedangkan menurut Winelti, Elfiswendi, dan Yeni (2012) yang melakukan penelitian mengenai pengaruh kepemilikan institutional, debt covenant dan Growth opportunities terhadap konservatisme akuntansi menunjukan hasil bahwa kepemilikan institutional memiliki pengaruh yang signifikan terhadap konservatisme sedangka debt covenant dan Growth opportunities tidak mempunyai pengaruh signifikan terhadap konservatisme.

Berdasarkan faktor-faktor tersebut di atas maka peneliti menggunakan faktor struktur kepemilikan institusional, Debt Covenant dan Growth Opportunities sebagai faktor yang diduga dapat menjelaskan variasi praktek konservatisme akuntansi. 
Rumusan masalah penelitian ini adalah: 1) Apakah sktruktur kepemilikan institusional berpengaruh terhadap tindakan konservatisme akuntansi? 2) Apakah Debt Covenant berpengaruh terhadap tindakan konservatisme akuntansi?

3) Apakah growth opportunities berpengaruh terhadap tindakan konservatisme akuntansi?

Tujuan penelian ini adalah : 1) Untuk membuktikan secara empiris pengaruh sktruktur kepemilikan institusional terhadap tindakan konservatisme akuntansi. 2) Untuk membuktikan secara empiris pengaruh Debt Covenant terhadap tindakan konservatisme akuntansi. 3) Untuk membuktikan secara empiris pengaruh growth opportunities terhadap tindakan konservatisme akuntansi.

\section{TINJAUAN PUSTAKA}

\section{Konservatisme Akuntansi}

Menurut FASB Statement of Concept No.2 Tahun 1987 dalam Utami (2011:3) konservatisme adalah reaksi hati-hati untuk menghadapi ketidakpastian dalam mencoba memastikan bahwa ketidakpastian dan risiko pada situasi bisnis telah dipertimbangkan. Suwardjono (2008:245) mendefinisikan konservatisme sebagai sikap atau aliran (mazhab) dalam menghadapi ketidakpastian untuk mengambil tindakan atau keputusan atas dasar munculan (outcome) yang terburuk dari ketidakpastian tersebut.

Definisi yang lebih deskriptif dikemukakan oleh Kieso dan Weygandt (2010) bahwa konservatisme berarti ketika dalam keraguan memilih solusi yang paling kecil kecenderungannya untuk overstate aset bersih dan laba bersih. Penjelasan lebih lanjut dikemukakan oleh Wolk et al, dalam Jamaan (2008) yang menyebutkan bahwa konservatisme sebagai preferensi terhadap metode-metode akuntansi yang menghasilkan nilai paling rendah untuk aset dan pendapatan, sementara nilai paling tinggi untuk utang dan biaya, atau menghasilkan nilai buku ekuitas yang paling rendah. Hal ini berakibat pada penundaan pengakuan aset dan pendapatan hingga aset atau pendapatan tersebut benar-benar telah diterima perusahaan walaupun kemungkinan adanya penerimaan aset sangat besar. Sebaliknya, pengakuan terhadap rugi atau biaya yang terjadi segera dilakukan.

Menurut Oktomegah (2012:37) konservatisme adalah reaksi yang cenderung mengarah pada sikap kehati-hatian atau disebut prudent reaction dalam menghadapi ketidakpastian yang melekat dalam perusahaan melingkupi aktivitas bisnis dan ekonomi untuk mencoba memastikan bahwa ketidakpastian dan risiko inheren yang menjadi ancaman dalam lingkungan bisnis sudah cukup dipertimbangkan.

Watts dalam Sari dan Adhriana (2009:3) mendefinisikan konservatisme sebagai perbedaan verifiabilitas yang diminta untuk pengakuan laba dibandingkan rugi. Watts juga menyatakan bahwa konservatisme akuntansi muncul dari insentif yang berkaitan dengan biaya kontrak, litigasi, pajak, dan politik yang bermanfaat bagi perusahaan untuk mengurangi biaya keagenan dan mengurangi pembayaran yang berlebihan kepada pihak-pihak 
seperti manajer, pemegang saham, pengadilan dan pemerintah. Selain itu, konservatisme juga menyebabkan understatement terhadap laba dalam periode kini yang dapat mengarahkan pada overstatement terhadap laba pada periode -periode berikutnya, sebagai akibat understatement terhadap biaya pada periode tersebut. Konservatisme merupakan prinsip yang penting dalam pelaporan keuangan agar pengakuan dan pengukuran aktiva serta laba dilakukan dengan penuh kehatihatian, karena aktivitas ekonomi dan bisnis dilingkupi oleh ketidakpastian (Wibowo dalam Astarini, 2011:18) Menurut Fivi dan Ira (2008:3) mengatakan definisi "konservatisme adalah memilih prinsip akuntansi yang mengarah pada minimalisasi laba kumulatif yang dilaporkan yaitu mengakui laba lebih lambat, mengakui pendapatan lebih cepat, menilai aset dengan nilai terendah dan menilai kewajiban dengan nilai yang tinggi. Konservatisme merupakan suatu prinsip kehati-hatian yang dihadapkan pada pilihan solusi yang sangat kecil kemungkinannya akan menghasilkan penetapan yang terlalu tinggi bagi aktiva dan laba. Konservatisme berarti jika ragu, maka pilihlah solusi yang sangat kecil kemungkinannya akan menghasilkan pendapatan yang terlalu tinggi bagi aset dan laba (Kieso dan Weygandt dalam Resti, 2012:12).

\section{Pengaruh \\ Institusional \\ Konservatisme \\ Kepemilikan
Terhadap}

Fala (2008) menyatakan

bahwa investor institusional mempunyai investasi ekuitas yang cukup besar sehingga investor institusional terdorong untuk mengawasi tindakan dan kinerja manajer lebih ketat. Jika investor institusional mempunyai kepemilikan saham dalam jumlah besar, maka mereka mempunyai hak untuk mengawasi perilaku dan kinerja manajemen. Investor cenderung berharap investasi yang mereka tanamkan di dalam perusahaan aman dan mempunyai tingkat return yang tinggi. Hal ini mendorong manajemen untuk melaporkan laba yang tidak konservatif agar pembagian dividen tinggi. Selain itu juga menarik para calon investor baru untuk menanamkan investasinya.

Lebih lanjut, Budiono (2005) menyatakan kepemilikan institusional memiliki kemampuan untuk mengendalikan pihak manajemen melalui proses monitoring secara efektif sehingga mengurangi tindakan manajemen melakukan manajemen laba.

Penelitian sebelumnya yang dilakukan oleh Deviyanti (2012), dan Winelti, dkk (2012) menunjukkan bahwa struktur kepemilikan institusional berpengaruh signifikan terhadap konservatisme akuntansi.

\section{Pengaruh Debt Covenant Terhadap Konservatisme}

Debt covenant hypothesis, menjelaskan bagaimana manajer menyikapi perjanjian utang. Manajer dalam menyikapi adanya pelanggaran atas perjanjian utang 
yang telah jatuh tempo, akan berupaya menghindarinya dengan memilih kebijakan akuntansi yang menguntungkan dirinya (Astarini, 2011:26). Dengan adanya kontrak hutang jangka panjang maka para pemberi pinjaman akan merasa terlindungi dari tindakan manajer seperti pembagian deviden yang berlebihan kepada kreditur. Apabila perusahaan cendrung melanggar perjanjian hutang maka manajer juga akan cendrung untuk memilih prosedur akuntansi yang dapat mentransfer laba pada periode mendatang ke periode berjalan karena dapat mengurangi resiko default. Namun, hal ini bertentangan dengan prinsip konservatisme yaitu mengakui laba atau pendapatan lebih lambat dan mengakui beban atau rugi yang lebih cepat.

Debt covenant memiliki peran terhadap konservatisme dalam dua cara. Pertama, bondholders dapat secara eksplisit menggunakan konservatisme akuntansi. Kedua, manajer dapat secara implisit menggunakan konservatisme akuntansi secara konsisten dalam rangka membangun reputasi untuk pelaporan keuangan yang konservatif (Harahap, 2012:4). Teori akuntansi positif memprediksi bahwa tingkat kesulitan keuangan perusahaan berpengaruh terhadap konservatisme akuntansi. Apabila perusahaan mengalami kesulitan keuangan otomatis akan dianggap sebagai pelanggaran kontrak. Dan hal ini disebabkan oleh kualitas kinerja manajer yang buruk. Keadaan ini akan mengakibatkan terjadinya penyimpangan kredit dan pengeluaran biaya, sehingga dapat berpengaruh terhadap konservatisme akuntansi dengan memilih metode akuntansi yang tidak konservatif.

Pengaruh Growth Opportunity Terhadap Konservatisme

Pada perusahaan yang menggunakan prinsip konservatisme terdapat cadangan tersembunyi yang digunakan untuk investasi, sehingga perusahaan yang konservatif identik dengan perusahaan yang tumbuh (Mayangsari dan Wilopo, 2002) dalam (Resti, 2012:25).

Pertumbuhan ini akan direspon positif oleh investor karena dari investasi yang dilakukan saat ini diharapkan perusahaan akan mendapatkan kenaikan arus kas dimasa depan. Penelitian Feltham dan Ohlson (1995) dan Penman (2001) dalam Widya (2005) dan Harahap (2012:4) menyatakan bahwa akuntansi konservatif merupakan konsep yang sesuai karena konsep tersebut menunjukan pertumbuhan suatu perusahaan karena aktiva netto yang dilaporkan lebih rendah dari nilai pasar, semakin tinggi tingkat pertumbuhan perusahaan maka semakin tinggi peluang untuk memilih akuntansi yang konservatif. Oleh karena itu penelitian ini memprediksi perusahaan yang tumbuh berpengaruh positif terhadap akuntansi konservatif.

Dari kerangka pemikiran diatas, dapat dibuat model penelitian sebagai berikut: 


\section{Gambar 1 \\ Model Penelitian}

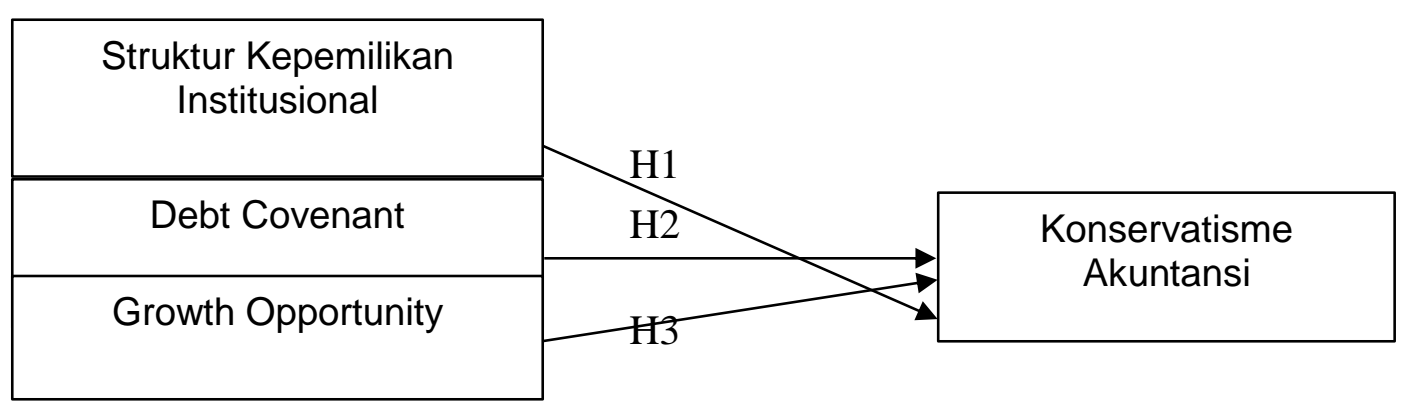

Variabel Independen

Variabel Dependen

\section{Hipotesis}

$\mathrm{H}_{1}=$ Struktur kepemilikan institusional berpengaruh terhadap konservatisme akuntansi

$\mathrm{H}_{2}=$ Debt Covenant berpengaruh terhadap konservatisme akuntansi

$\mathrm{H}_{3}=$ Growth Opportunity berpengaruh terhadap konservatisme akuntansi

\section{METODE PENELITIAN}

Populasi penelitian ini adalah perusahaan real estate dan property yang terdaftar di Bursa Efek Indonesia (BEI). Pemilihan sampel penelitian berdasarkan pada purposive sampling. Setelah dilakukan sampling dengan kriteria diatas, didapatkan sampel dalam penelitian adalah sebanyak 28 perusahaan real estate dan property.

Data yang digunakan dalam penelitian ini adalah data sekunder yaitu ICMD, IDX Statistics, IDX Factbook, harga saham penutupan akhir tahun dan jumlah saham yang beredar pada akhir tahun; Laporan keuangan tahunan dan catatan atas laporan keuangan. Metode pengumpulan data yang digunakan dalam penelitian ini adalah metode dokumentasi.
Analisis statistik deskriptif digunakan untuk mengetahui nilai rata-rata, minimun, maksimum dan standar deviasi. Selain itu, dilakukan uji asumsi klasik (normality, multicollinearity, autokorelasi dan heterokedastisitas). Pengujian hipotesis pengaruh variabel struktur kepemilikan institusional, Debt Covenant dan Growth Opportunities terhadap konservatisme akuntansi $\left(\mathrm{H}_{1}, \mathrm{H}_{2}, \mathrm{H}_{3}\right)$ digunakan alat analisis regresi berganda.

\section{HASIL DAN PEMBAHASAN Analisis Statistik Deskriptif Variabel}

Berdasarkan hasil pengolahan data dengan menggunakan SPSS (Statsitical Product and Service Solutions) versi 16.0 diperoleh hasil perhitungan sebagai berikut: 
Tabel 1.

Analisis Statistik Deskriptif

Descriptive Statistics

\begin{tabular}{|l|r|r|r|r|r|}
\hline & $\mathrm{N}$ & Minimum & Maximum & Mean & $\begin{array}{c}\text { Std. } \\
\text { Deviation }\end{array}$ \\
\hline SKI & 84 & 17.53 & 95.18 & 63.7777 & 21.55086 \\
Debt Covenant & 84 & .07 & .74 & .4251 & .14765 \\
Growth Opportunities & 84 & .29 & 4.84 & 1.5287 & 1.03199 \\
Konservatime & 84 & -.718 & 1.398 & .05224 & .390493 \\
Akuntansi & & & & & \\
Valid N (listwise) & 84 & & & & \\
\hline
\end{tabular}

Sumber: Data olahan, 2015

\section{Hasil Uji Outlier}

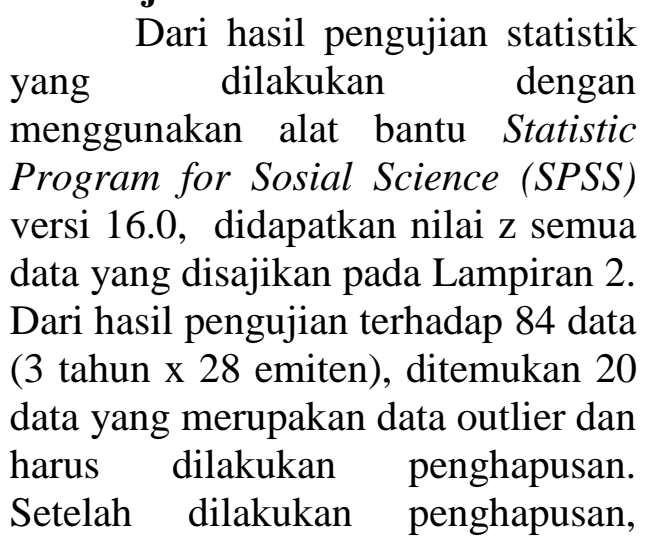

maka data penelitian berkurang menjadi 64 data. Setelah dilakukan pengujian data outlier, maka pengujian selanjutnya adalah pengujian normalitas dan pengujian asumsi klasik.

\section{Hasil Uji Kualitas Data}

\section{Hasil Uji Normalitas Data}

Hasil Uji Normalitas Data dapat dilihat pada Tabel 2 berikut ini :

Tabel 2

Hasil Uji Normalitas Data

One-Sample Kolmogorov-Smirnov Test

\begin{tabular}{|ll|r|}
\hline & & Unstandardized Residual \\
\hline \multirow{2}{*}{ Normal Parameters $^{\mathrm{a}, \mathrm{b}}$ ( } & $\mathrm{N}$ & 64 \\
& Mean & .0000000 \\
Most Extreme & Std. Deviation & .21274286 \\
Differences & Absolute & .160 \\
& Positive & .160 \\
& Negative & -.149 \\
& Kolmogorov- & 1.283 \\
& Smirnov Z & .075 \\
& Asymp. Sig. (2- & \\
& tailed) & \\
\hline
\end{tabular}

a. Test distribution is Normal.

b. Calculated from data.

Sumber: Data olahan, 2015 
Berdasarkan Tabel 4.2 dapat dilihat Asym. Sig 0,079 lebih besar dari 0,05 maka dapat disimpulkan bahwa data model ini adalah data terdistribusi normal.

\section{Hasil Uji Asumsi Klasik \\ Hasil Uji Autokorelasi}

Hasil uji Autokorelasi dapat dilihat pada Tabel 3 berikut ini :

Tabel 3

Hasil Uji Autokorelasi

\begin{tabular}{|l|r|r|r|r|c|}
\hline Model & \multicolumn{1}{|c|}{$\mathrm{R}$} & R Square & \multicolumn{1}{c|}{$\begin{array}{c}\text { Adjusted R } \\
\text { Square }\end{array}$} & $\begin{array}{c}\text { Std. Error of } \\
\text { the Estimate }\end{array}$ & $\begin{array}{l}\text { Durbin- } \\
\text { Watson }\end{array}$ \\
\hline 1 & $.226^{\mathrm{a}}$ & .051 & .004 & .217997 & 2.115 \\
\hline
\end{tabular}

Sumber: Data olahan, 2015

Dari hasil Durbin-Watson pada model regresi di atas menghasilkan nilai 2,115. Sedangkan dari tabel statistik Durbin-Watson, diketahui bahwa du (durbin upper): 1.6946 . Dari nilai du dan dw. Dapat dibuat persamaan yang sesuai adalah:

$$
\text { du }<\text { d }<4 \text {-du }
$$

$$
\begin{gathered}
1.6946<2,115<4-1.6946 \\
1.6946<2,115<2,3054
\end{gathered}
$$

Maka dapat disimpulkan persamaan regresi tidak ada autokorelasi negatif atau positif sehingga model ini layak untuk digunakan.

Hasil Uji Multikolinearitas

Hasil Uji Multikolinearitas dapat dilihat pada Tabel 4.5. berikut ini

Tabel 4.5

Hasil Uji Multikolinearitas

\begin{tabular}{|l|r|c|}
\hline \multirow{2}{*}{ Model } & \multicolumn{2}{|c|}{ Collinearity Statistics } \\
\cline { 2 - 3 } & Tolerance & VIF \\
\hline 1 (Constant) & .888 & \\
SKI & .1 .126 \\
Debt Covenant & .892 & 1.121 \\
Growth Opportunities & .910 & 1.099 \\
\hline
\end{tabular}

a. Dependent Variable: Konservatisme

Sumber: Data olahan, 2015

Dari hasil uji multikolinearitas yang dapat dilihat pada Tabel 4.3. dapat disimpulkan tidak terjadi multikolinearitas pada model regresi karena nilai Tolerance pada model ini lebih besar dari 0,10 dan nilai VIF lebih kecil dari 10.

\section{Hasil Uji Heterokedastisitas}

Hasil Uji Heterokedastisitas dapat dilihat pada Gambar 4.1 berikut ini : 
Gambar 4.1

Hasil Uji Heteroskedastisitas

Scatterplot

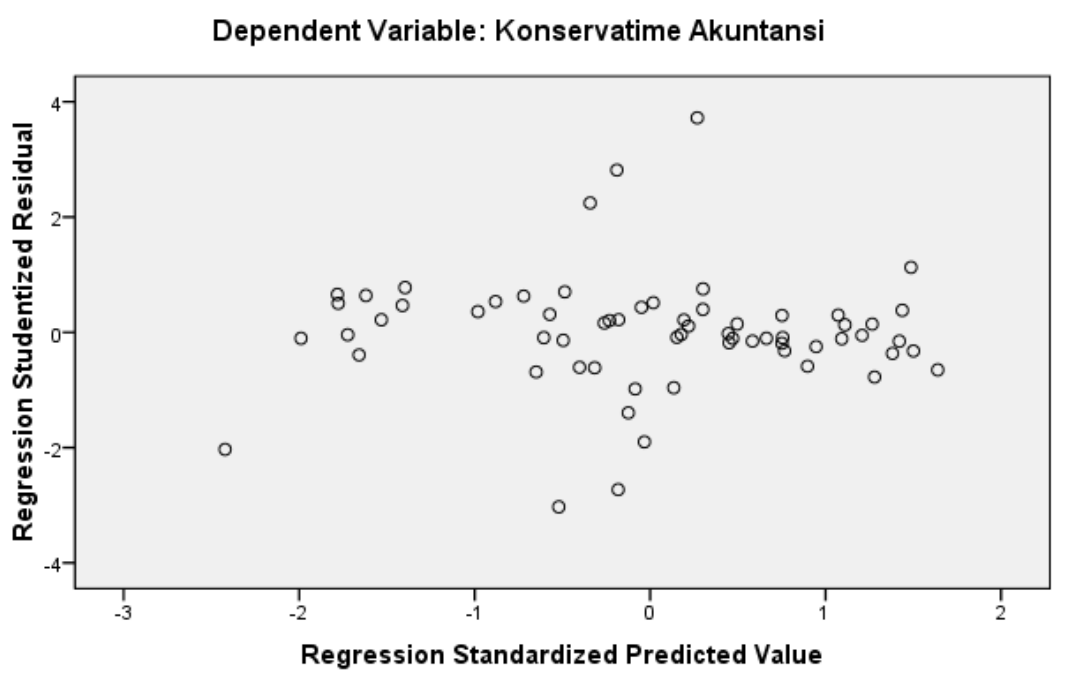

Sumber: Data olahan, 2015

Berdasarkan grafik scatterlot dapat dilihat bahwa titik-titik data tersebar secara acak dan tidak

\section{Hasil Uji Hipotesis dan}

Pembahasan

Hasil Pengujian Regresi Linier

Berganda

membentuk suatu pola sehingga dapat dikatakan bahwa model regresi ini tidak terjadi heteroskedastisitas.

Secara parsial pengaruh dari tiga variabel independen tersebut terhadap Konservatisme dipaparkan

Tabel 6 pada tabel berikut:

Persamaan Regresi Linier Berganda

\begin{tabular}{|l|r|r|r|r|r|}
\hline \multirow{2}{*}{ Model } & \multicolumn{2}{|c|}{$\begin{array}{c}\text { Unstandardized } \\
\text { Coefficients }\end{array}$} & $\begin{array}{c}\text { Standardize } \\
\mathrm{d} \\
\text { Coefficients }\end{array}$ & & \\
\cline { 2 - 5 } & \multicolumn{1}{|c|}{$\mathrm{B}$} & \multicolumn{1}{c|}{$\begin{array}{c}\text { Std. } \\
\text { Error }\end{array}$} & \multicolumn{1}{c|}{ Beta } & \multicolumn{1}{c|}{$\mathrm{t}$} & \multicolumn{1}{c|}{ Sig. } \\
\hline 1 (Constant) & .110 & .160 & & .692 & .492 \\
SKI & -.002 & .001 & -.149 & -1.119 & .267 \\
Debt Covenant & .117 & .221 & .070 & .529 & .599 \\
Growth Opportunities & -.061 & .041 & -.197 & -1.494 & .140 \\
\hline
\end{tabular}

Sumber: Data olahan, 2015

Dari tabel 6 dapat disusun persamaan regresi linier berganda sebagai berikut :

$$
\begin{aligned}
& Y=0,110-0,149 X_{1}+0,070 X_{2}- \\
& 0,197 X_{3}
\end{aligned}
$$

Berdasarkan persamaan regresi linier berganda di atas diperoleh: 
1. Konstanta bernilai (+) 0,110 . Konstanta tersebut mengindikasikan bahwa jika semua variabel independen diasumsikan tidak dimasukkan ke dalam model penelitian, maka konservatisme bernilai (+) 0,110.

2. Koefisien regresi Kepemilikan Institusional sebesar (-) 0,149 . Koefisien tersebut mengindikasikan adanya hubungan negatif antara variabel Kepemilikan Institusional terhadap Konservatisme. Nilai koefisien regresi 0,149 mengindikasikan bahwa jika variabel Kepemilikan Institusional naik sebesar 1 satuan maka variabel Konservatisme akan turun sebesar 0,149.

3. Koefisien regresi Debt Covenant sebesar (+) 0,070 Koefisien tersebut mengindikasikan adanya hubungan positif antara variabel Debt Covenant terhadap
Konservatisme. Nilai koefisien regresi 0,070 mengindikasikan bahwa jika variabel Debt Covenant naik sebesar 1 satuan maka variabel Konservatisme akan naik sebesar 0,070.

4. Koefisien regresi Growth Opportunities sebesar (-) 0,197. Koefisien tersebut mengindikasikan adanya hubungan negatif antara variabel Growth Opportunities terhadap Konservatisme. Nilai koefisien regresi (-) $\quad 0,197$ mengindikasikan bahwa jika variabel Growth Opportunities naik sebesar 1 satuan maka variabel Konservatisme akan turun sebesar 0,074.

\section{Hasil Pengujian Hipotesis (Uji t)}

Berikut ini adalah hasil Uji-t yang digunakan untuk melihat signifikansi dari pengaruh variabel independen secara individu terhadap variabel dependen:

\section{Tabel 7}

Hasil Uji t

\begin{tabular}{|l|r|r|r|r|r|}
\hline \multirow{2}{*}{ Model } & \multicolumn{2}{|c|}{$\begin{array}{r}\text { Standardiz } \\
\text { ed } \\
\text { Unstandardized } \\
\text { Coefficients }\end{array}$} & $\begin{array}{c}\text { Coeficien } \\
\text { ts }\end{array}$ & & \\
\cline { 2 - 5 } & \multicolumn{1}{|c|}{ B } & \multicolumn{1}{c|}{$\begin{array}{c}\text { Std. } \\
\text { Error }\end{array}$} & Beta & \multicolumn{1}{c|}{$\mathrm{t}$} & \multicolumn{1}{c|}{ Sig. } \\
\hline 1 (Constant) & .110 & .160 & & .692 & .492 \\
SKI & -.002 & .001 & -.149 & -1.119 & .267 \\
Debt Covenant & .117 & .221 & .070 & .529 & .599 \\
Growth Opportunities & -.061 & .041 & -.197 & -1.494 & .140 \\
\hline
\end{tabular}

Sumber: Data olahan, 2015

Dari hasil Uji-t dapat dilakukan pembahasan hipotesis yang diajukan sebagai berikut :

\section{Hasil Pengujian Hipotesis 1}

Pengujian ini dilakukan untuk menguji apakah variabel independen Kepemilikan
Institusional 
berpengaruh secara parsial terhadap Konservatisme.

Nilai $t_{\text {tabel }}$ dengan tingkat signifikansi $\alpha=0,05$ dengan degree of freedom $(\mathrm{df})=64-3-1=60$ adalah 2,00030. Berdasarkan Uji-t diperoleh hasil bahwa nilai $t_{\text {hitung }}$ sebesar -1,119 dengan tingkat signifikansi 0,267. Karena:

a. Tingkat signifikansi 0,267 lebih besar dari $0,05(0,267>0,05)$

b. Nilai $t_{\text {hitung }}<t_{\text {tabel }}(1,119<$ 2,00030)

Maka secara parsial variabel independen

Kepemilikan

Institusional tidak berpengaruh signifikan terhadap variabel dependen Konservatisme. Dengan demikian Hipotesis 1 Ditolak.

Hasil penelitian ini sejalan hasil penelitian sebelumnya yang dilakukan oleh Widayati (2011) dan Brilianti (2013) yang menunjukkan hasil bahwa struktur kepemilikan institutional tidak memiliki pengaruh yang signifikan terhadap konservatisme. Hal ini menunjukkan bahwa kepemilikan institutional bukan merupakan prediktor yang dapat mempengaruhi konservatisme akuntansi dalam suatu perusahaan.

Proporsi Struktur Kepemilikan Institusional pada perusahaan perbankan listing di BEI selama periode pengamatan tergolong masih rendah. Dilihat pada analisis statistik deskriptif memberikan hasil nilai rata-rata yaitu sebesar 63.7777. Hal tersebut menunjukkan bahwa manajemen perusahaan sampel sebagian besar masih memiliki saham pada perusahaan yang dikelolanya. Rendahnya Kepemilikan Institusional dalam penelitian ini menunjukkan bahwa aktivitas monitoring yang dilakukan oleh kepemilikan institusional dalam suatu perusahaan belum optimal digunakan sebagai alat untuk memonitor manajemen. Hal ini bisa menjadi penyebab kepemilikan institusional tidak memiliki pengaruh yang signifikan.

\section{Hasil Pengujian Hipotesis 2}

Pengujian ini dilakukan untuk menguji apakah variabel independen Debt Covenant berpengaruh secara parsial terhadap Konservatisme.

Nilai $t_{\text {tabel }}$ dengan tingkat signifikansi $\alpha=0,05$ dengan degree of freedom $(\mathrm{df})=64-3-1=60$ adalah 2,00030. Berdasarkan Uji-t diperoleh hasil bahwa nilai $t_{\text {hitung }}$ sebesar 0,529 dengan tingkat signifikansi 0,599. Karena:

a. Tingkat signifikansi 0,599 lebih besar dari 0,05 $(0,599>0,05)$

b. Nilai $t_{\text {hitung }}<t_{\text {tabel }}(0,529<$ 2,00030)

Maka secara parsial variabel independen Debt Covenant berpengaruh signifikan terhadap variabel dependen Konservatisme. Dengan demikian Hipotesis 2 Ditolak.

Hasil penelitian ini sejalan hasil penelitian sebelumnya yang dilakukan oleh Astarini (2011) yang menyatakan bahwa Debt Covenant tidak berpengaruh terhadap Konservatisme. Artinya bahwa hasil penelitian ini mendukung hasil penelitian Astarini (2011) mengenai Debt Covenant yang tidak berpengaruh terhadap konservatisme akuntansi. Hal ini menunjukkan bahwa Growth Opportunities bukan merupakan prediktor yang dapat mempengaruhi konservatisme akuntansi dalam suatu perusahaan. 
Adapun alasan yang menjelaskan mengapa debt covenant tidak berpengaruh terhadap konservatisme akuntansi karena debt covenant pada perusahaan perusahaan listing di BEI selama periode pengamatan tinggi yang ditunjukkan dengan rata-rata 0,4251 . Agar mendapatkan modal/hutang dari pihak eksternal maka perusahaan akan memberikan gambaran tentang kegiatan operasi yang baik serta hasil laba yang tinggi. Perusahaan akan melakukan motif ekonomi yang bisa membuat perusahaan menjadi terlihat lebih eksis dan menghindarkan dari kerugian yang besar sehingga laporan keuangan yang dibuat oleh pihak manajemen tidak lagi konservatif.

\section{Hasil Pengujian Hipotesis 3}

Pengujian ini dilakukan untuk menguji apakah variabel independen Growth Opportunities (SKM) berpengaruh secara parsial terhadap Konservatisme.

Nilai $t_{\text {tabel }}$ dengan tingkat signifikansi $\alpha=0,05$ dengan degree of freedom $(\mathrm{df})=64-3-1=60$ adalah 2,00030. Berdasarkan Uji-t diperoleh hasil bahwa nilai $t_{\text {hitung }}$ sebesar -1,494 dengan tingkat signifikansi 0,140. Karena:

c. Tingkat signifikansi 0,140 lebih besar dari $0,05(0,140>0,05)$

d. Nilai $t_{\text {hitung }}<t_{\text {tabel }}(1,494<$ 2,00030)

Maka secara parsial variabel independen Growth Opportunities tidak berpengaruh signifikan terhadap variabel dependen
Konservatisme. Dengan demikian Hipotesis 3 Ditolak.

Hasil penelitian ini sejalan hasil penelitian sebelumnya yang dilakukan oleh Astarini (2011) yang menyatakan bahwa Growth Opportunities tidak berpengaruh terhadap Konservatisme. Artinya bahwa hasil penelitian ini mendukung hasil penelitian Astarini (2011) mengenai Growth Opportunities yang tidak berpengaruh terhadap konservatisme akuntansi. Hal ini menunjukkan bahwa Growth Opportunities bukan merupakan prediktor yang dapat mempengaruhi konservatisme akuntansi dalam suatu perusahaan.

Growth Opportunity selama periode pengamatan masih rendah. Dilihat pada analisis statistik deskriptif memberikan hasil nilai rata-rata yaitu sebesar 1,5287. Pertumbuhan yang kecil ini menandakan bahwa perusahaan tidak konservatif. Karena pada dasarnya, perusahaan yang menggunakan prinsip konservatisme terdapat cadangan tersembunyi yang digunakan untuk investasi, sehingga perusahaan yang konservatif identik dengan perusahaan yang tumbuh (Mayangsari dan Wilopo, 2002) dalam (Resti, 2012:25). Tidak adanya pengaruh growth opportunity terhadap konservatisme disebabkan karena kecilnya kesempatan investasi maka pasar akan menilai negatif atas investasi yang dilakukan perusahaan.

\section{Koefisien Determinasi} Hasil uji koefisien determinasi adalah sebagai berikut: 
Tabel 7

Uji Koefisien Determinasi

Model Summary ${ }^{b}$

\begin{tabular}{|l|r|r|r|r|r|}
\hline Model & \multicolumn{1}{|c|}{$\mathrm{R}$} & R Square & $\begin{array}{c}\text { Adjusted R } \\
\text { Square }\end{array}$ & $\begin{array}{l}\text { Std. Error of } \\
\text { the Estimate }\end{array}$ & $\begin{array}{l}\text { Durbin- } \\
\text { Watson }\end{array}$ \\
\hline 1 & $.226^{\mathrm{a}}$ & .051 & .004 & .217997 & 2.115 \\
\hline
\end{tabular}

Sumber: Data olahan, 2015

Berdasarkan Tabel 7 dapat dilihat bahwa nilai koefisien determinasi $(R$ square $)=0,051$ ini berarti bahwa variasi dari variabel dependen (Konservatisme) mampu dijelaskan oleh variabel independen sebesar 0,051 atau $5,1 \%$. Dengan kata lain bahwa 5,1\% konservatisme akuntansi di perusahaan manufaktur mampu dijelaskan oleh variabel Kepemilikan Institusional, Debt Covenant dan Growth Opportunities sedangkan sisanya $94,9 \%$ dijelaskan oleh faktor lain yang tidak dijelaskan dalam penelitian ini.

\section{PENUTUP}

Berdasarkan hasil analisis data dan pembahasan yang telah dikemukakan, dapat diambil kesimpulan sebagai berikut :

1. Secara parsial variabel Kepemilikan Institusional tidak berpengaruh signifikan terhadap variabel Konservatisme.

2. Secara parsial variabel Debt Covenant tidak berpengaruh signifikan terhadap variabel Konservatisme.

3. Secara parsial variabel Growth Opportunities tidak berpengaruh signifikan terhadap variabel Konservatisme.

Untuk peneliti selanjutnya, hasil penelitian ini dapat digunakan sebagai referensi dalam penelitian lebih lanjut. Salah satunya yaitu memperpanjang periode penelitian. Dengan demikian mampu memberikan gambaran kondisi Konservatisme Akuntansi secara lebih luas.

\section{DAFTAR PUSTAKA}

Astarini, Dwi. 2011. Analisis FaktorFaktor Yang Mempengaruhi Pilihan Perusahaan Terhadap Konservatisme Akuntansi. Skripsi Universitas Pembangunan Nasional Veteran

Belkaoui, Ahmed, Herman Wibowo danMarianus Sinaga. 1997. Teori Akuntansi Jilid 1 Edisi Kedua Cetakan Ketiga. Erlangga

Brilianti, Dinny Prastiwi. 2013. Faktor-Faktor yang Mempengaruhi Penerapan. Konservatisme Akuntansi Perusahaan. Skripsi. Universitas Negeri. Semarang.

Boediono, Gideon SB. 2005. Kualitas Laba: Studi Pengaruh Mekanisme Corporate Governace dan Dampak Manajemen Laba dengan Menggunakan Analisis Jalur. Simposium Nasional Akuntansi VIII 
Deviyanti, Dyahayu Artika. 2012. Analisis Faktor Faktor yang Mempengaruhi Penerapan Konservatisme Dalam akuntansi. Skripsi. Universitas Diponegoro

Evana, Einde. 2011. Faktor-Faktor yang Mempengaruhi Pemilihan Akuntansi Konservatif Pada Perusahaan Yang Terdaftar Di Bursa Efek Indonesia. Skripsi. Universitas Lampung

Fala, Dwi Yana Amalia. 2007. Pengaruh konservatisme akuntansi terhadap penilaian ekuitas perusahaan dimoderasi oleh Good Corporate Governance. Simposium Nasional Akuntansi X, Makasar, 2628 Juli 2007

Fivi Anggraini dan Ira Trisnawati. 2008. Pengaruh Earning Manajement Terhadap Konservatisma Akuntansi. Jurnal Bisnis dan Akuntansi Vol. 10, No. 1. Hlm. 23 36.

Harahap, Sofyan Syafri. 2012. Analisa Kritis Atas Laporan Keuangan, Grafindo Persada, Jakarta.

Jama'an. 2008. Pengaruh Mekanisme Corporate Governance, Dan Kualitas Kantor Akuntan Publik Terhadap Integritas Informasi Laporan Keuangan (Studi Pada Perusahaan Publik Di BEJ), Tesis Strata-2, Program Studi Magister Sains Akuntansi Universitas Diponegoro, Semarang.
Kieso, Weygandt, dan Warfield. 2010. Akuntansi Intermediate, Edisi Kedua Belas, Erlangga, Jakarta.

Okto Megah, Calvin. 2012. Faktor Faktor Yang Mempengaruhi Penerapan Konservatisme Pada Perusahaan Manufaktur di BEI. Jurnal Vol 1, NO. 1, Januari 2012

Resti, 2012. Analisis Faktor Faktor Yang Mempengaruhi Konservatisme Akuntansi. Skripsi. Universitas Hassanudin Makasar

Sabrinna, Anindhita Ira. 2010. Pengaruh Corporate Governance Dan Struktur Kepemilikan Terhadap Kinerja Perusahaan. Skripsi. Universitas Diponegoro

Sari, Cynthia dan Desi Adhariani. 2009. Konservatisme Akuntansi dan Faktor Faktor yang Mempengaruhinya.

Makalah SNA XII.

Suwardjono. 2008. Teori Akuntansi, Perekayasaan Pelaporan Keuangan, BPFE UGM. Yogyakarta

Utami, Rena Fitriana. 2011. Influence Risk of The Litigation and The Financial Distress Company's Accounting Conservatism. Jurnal. Universitas Komunikasi Indonesia

Wahyudi, Untung dan Hartini p. pawestri. 2006. Implikasi Struktur Kepemilikan Terhadap Nilai Perusahaan: Dengan Keputusan Keuangan Sebagai Variabel Intervening. Simposium 
Nasional Akuntansi (SNA)

IX, Padang.

Watts, R. dan Zimmerman J. 1986.

Positive Theory of

Accounting. Englewood

Cliffs, NJ: Prentice-Hall.

Widayati, Endah. 2011. Analisis

Faktor-Faktor yang

Mempengaruhi Pilihan

Perusahaan terhadap

Konservatisma Akuntansi.

Skripsi. Universitas

Diponegoro.

Widya. 2005. Analisis Faktor-Faktor yang Mempengaruhi Pilihan Perusahaan Terhadap Akuntansi Konservatif.

Simposium Nasional Akuntansi VII Denpasar: 709-724.

Winelti, Reza. Elfiswandi. Yeni, Fitri. 2012. Pengaruh Struktur Kepemilikan, Debt Covenant dan Growth Opportunities Terhadap Konservatisme Akuntansi pada Perusahaan Manufaktur yang terdaftar di Bursa Efek Indonesia. Jurnal. Univesitas Padang

Yadiati, Winwin. 2007. Teori Akuntansi Suatu Pengantar. Edisi Pertama. Cetakan Pertama. Kencana Prenada Media Group. 